"An evaluation of bank acquisition using an accounting based measure: a case of Amalgamated Bank of South Africa and Barclays Bank Plc."

\begin{tabular}{|c|c|c|}
\hline AUTHORS & \multicolumn{2}{|l|}{ Mbuyiseni Goodlife Ntuli } \\
\hline ARTICLE INFO & \multicolumn{2}{|c|}{$\begin{array}{l}\text { Mbuyiseni Goodlife Ntuli (2017). An evaluation of bank acquisition using an } \\
\text { accounting based measure: a case of Amalgamated Bank of South Africa and } \\
\text { Barclays Bank Plc.. Banks and Bank Systems, 12(1-1), 160-165. } \\
\text { doi:10.21511/bbs.12(1-1).2017.09 }\end{array}$} \\
\hline DOI & \multicolumn{2}{|c|}{ http://dx.doi.org/10.21511/bbs.12(1-1).2017.09 } \\
\hline RELEASED ON & \multicolumn{2}{|l|}{ Friday, 05 May 2017} \\
\hline RECEIVED ON & \multicolumn{2}{|l|}{ Friday, 06 January 2017} \\
\hline ACCEPTED ON & \multicolumn{2}{|l|}{ Friday, 10 February 2017} \\
\hline & \multicolumn{2}{|l|}{$(c c)$ BY-NC } \\
\hline LICENSE & \multicolumn{2}{|c|}{$\begin{array}{l}\text { This work is licensed under a Creative Commons Attribution-NonCommercial } 4.0 \\
\text { International License }\end{array}$} \\
\hline JOURNAL & \multicolumn{2}{|l|}{ "Banks and Bank Systems" } \\
\hline ISSN PRINT & \multicolumn{2}{|l|}{$1816-7403$} \\
\hline ISSN ONLINE & \multicolumn{2}{|l|}{$1991-7074$} \\
\hline PUBLISHER & \multicolumn{2}{|c|}{ LLC "Consulting Publishing Company "Business Perspectives" } \\
\hline FOUNDER & \multicolumn{2}{|c|}{ LLC "Consulting Publishing Company "Business Perspectives" } \\
\hline \multirow[b]{2}{*}{ NUMBER OF REFERENCES } & & $\begin{array}{ll}\text { E-:- } \\
\text { E-: }\end{array}$ \\
\hline & NUMBER OF FIGURES & NUMBER OF TABLES \\
\hline 28 & 1 & 1 \\
\hline
\end{tabular}

(C) The author(s) 2023. This publication is an open access article. 


\title{
An evaluation of bank acquisition using an accounting based measure: a case of Amalgamated Bank of South Africa and Barclays Bank Plc
}

\begin{abstract}
In 2005, Barclays Bank Plc acquired 56.4 percent stake of Amalgamated Bank of South Africa (ABSA). The performance of this acquisition has never been evaluated. Therefore, the purpose of this article is to evaluate the performance of the acquired ABSA through an accounting based measure. The primary source of data was the 2004-2015 ABSA audited financial statements. The audited financial statements are publicly available. The period 2004-2015 includes a period before, during and after the acquisition. In this article, a financial statement analysis method through an accounting based measure was the preferred research method. The financial statement analysis method was preferred because of its strength and ability to assess viability, stability and profitability by using formulae, ratios and calculations. Therefore, this article used financial formulae and ratios as acceptable accounting based measures to evaluate the performance of the acquired ABSA. The major finding is that the acquired ABSA is doing better than at the pre-acquisition stage and the share price of the acquired ABSA has been increasing since 2005 to 2015 .
\end{abstract}

Keywords: accounting-based measures, acquisition, evaluation, performance, Amalgamated Bank of South Africa. JEL Classification: G34, G21.

Received on: $6^{\text {th }}$ of January, 2017.

Accepted on: 10 ${ }^{\text {th }}$ of February, 2017.

\section{Introduction}

This article seeks to evaluate the performance of the South African banking institution that was acquired by Barclays Plc. The accounting based measure will be used as an evaluation tool. There has been a plethora of studies conducted on the topic of mergers, and acquisitions in various sectors, including the banking sector (Uremadu et al., 2016; Sabri et al., 2015; Lin et al., 2013; Hitt et al., 2012; Alexandridis et al., 2010). However, the banking industry is still experiencing an unprecedented level of mergers and acquisitions (Pilloff, 1996). The reason for mergers and acquisitions is based on a belief that gains can accrue through expense reduction, increased market power, reduced eamings volatility, and scale and scope economies (Pilloff, 1996). Therefore, in this article, I intend to use the unit enterprise called Amalgamated Bank of South Africa (ABSA) to investigate the profitability of an acquisition of a South African financial institution by an offshore investor through an accounting based measure.

The ABSA Barclays merger represented a case of the acquisition masked in a form of merger. In May 2005, Barclays Bank of the United Kingdom purchased $56.4 \%$ stake in ABSA as part of its drive to expand its global product and international retail and commercial banking businesses to untapped markets outside the UK (ABSA Annual Report, 2015).

(c) Mbuyiseni Goodlife Ntuli, 2017.

Mbuyiseni Goodlife Ntuli, Dr., Lecturer at University of KwaZuluNatal: Graduate School of Business and Leadership, South Africa.

This is an Open Access article, distributed under the terms of the Creative Commons Attribution-NonCommercial 4.0 International license, which permits re-use, distribution, and reproduction, provided the materials aren't used for commercial purposes and the original work is properly cited.
A merger can be defined as the combination of two or more companies into one new entity, whilst the acquisition is buying more than $51 \%$ of stock or assets of another entity. The main difference between a merger and an acquisition lies in the way in which the combination of the two companies is brought about. For example, assume that companies $\mathrm{A}$ and $\mathrm{B}$ are existing financial institutions. Company $\mathrm{A}$ is a high street bank with a large commercial customer base. Company B is a building society or similar organization specializing in providing home loans for the domestic market. Both companies may consider that a merger would produce benefits, as it would make the commercial and domestic customer bases available to the combined company. There will obviously be some complications and difficulties involved, but there are some obvious potential synergies available. Therefore, in this article, I intend to contribute in the field of knowledge by evaluating a South African bank acquisition using an accounting based measure.

Problem statement. Most scholars (Pahuja and Aggarwal, 2016; Irfan Shakoor et al., 2014; Arvanitis and Stucki, 2015; Uhlenbruck et al., 2016; Yadav, 2016; Ahmed and Nadeem, 2015) have argued that acquisition stimulates performance, because the acquiring firm might have a larger market power and other qualitative and quantitative factors. However, the acquisition of the Amalgamated Bank of South Africa by Barclays Plc has never been evaluated. Even though, before Barclays Plc acquired ABSA, there were speculations that the acquisition would be profitable and benefit the South African economy. When the acquisition occurred, there was a huge cash injection into the South African economy and that might have boosted the Gross Domestic Product (GDP). Subsequently, the share price immediately increased. However, not much effort has been made to follow up on 
the performance of the acquisition. This article seeks to evaluate the performance of the acquisition, through the accounting based measure, with more emphasis on the profitability of the acquisition.

Aim. This article aims to evaluate the performance of the acquisition of ABSA by Barclays Plc. during the period of 2006-2015 using the accountingbased measure.

\section{Objectives}

- To investigate the performance of the acquisition of ABSA by Barclays Bank Plc. during 2006-2015 period.

- To determine whether the acquisition of ABSA by Barclays was profitable by comparing 2004, 2005 \& 2006 period.

- To examine the debt equity ratio of ABSA after the acquisition by Barclays Plc in 2004, 2005 \& 2006 period.

\section{Literature review}

Mergers and acquisitions are increasing day by day in a globalized era. Merger takes place when two or more companies with their joint consensus agree to do business with the same name or with another name. Acquisition is something totally different from merger. In acquisition, the acquiring company uses its own name. The fundamental question is why organizations do mergers and acquisitions? Many reasons exist behind mergers and acquisitions such as increasing market share, achieving economy of scale and economy of scope, increasing profits, synergy and diversifing the risk, actually, the emergence of mergers and acquisitions changed the overall financial industry (Muhammad, Muhammad, Muhammad, \& Waseem, 2014). However, a number of studies have been conducted over the years on the topic of mergers and acquisitions (Uremadu et al., 2016; Sabri et al., 2015; Lin et al., 2013; Hitt et al., 2012; Alexandridis et al., 2010), precisely measuring profitability, leverage impacts, shareholder's wealth and efficiency of mergers and acquisitions. Mergers and acquisitions are considered as a strategy to gain profitability, avoid insolvency, improve asset quality and maximize return on assets and equity (Akhtar and Iqbal, 2014). Weinberg (2007) asserted that after mergers, many merged organizations product prices fluctuates positively for short time period. Acquiring corporation's operations performance flourishes due to the impact of mergers. It also has been viewed by Mantravidi and Reddy (2008), as cited in Irfan Shakoor et al. (2014) that merger has a minor positive impact on the profitability of the organization. This view is affirmed by Alexandridis et al. (2010) that the fundamental aim of mergers and acquisitions is the generation of synergies that can, in turn, foster corporate growth, increase market power, boost profitability, and improve shareholders' wealth. A merger or an acquisition in a company can be defined as the combination of two or more companies into one new company or corporation. The main difference between a merger and an acquisition lies in the way in which the combination of the two companies is brought about (Roberts et al., 2010). In a merger, there is usually a process of negotiation involved between the two companies prior to the combination taking place. Collett (2015) argued that the merging company is expected to conduct extensive due diligence and request extensive representations and warranties from the target company and the shareholders in the merger agreement. After preliminary due diligence has been performed, the acquirer narrows their list of potential targets and signs a confidentiality agreement with targets they want to pursue further. This view by collections is well articulated in Chen et al.'s (2016) study that the in-depth due diligence starts immediately after the confidentiality agreement is signed. At this stage, acquirers have access to private information from the target, but acquirers' access to private information is limited for a number of reasons (Chen et al., 2016). First, the offer price is not set. Therefore, targets have an incentive to put their best foot forward and the information they provide is likely optimistic. Despite the fact that the acquirer has access to more private information, publicly available information still plays an important role, because it enables the acquirer to compare and contrast the information provided by the target to independent sources, including peer firm financial statements. This comparison is seen as vital in obtaining an unbiased view of the target firm.

However, it is presumed that foreign banks add value to domestic competition, increase access to financial services, enhance financial and economic performance of their borrowers, and bring greater financial stability (Claessens and Horen, 2014). This notion of merger value is defined by Linde and Siebert (2016) as the difference between post and pre-merger profits. To explore this relationship, we take our fitted merger values and use them to predict merger performance. Linde and Siebert (2016) define merger performance as the difference between the acquiring firm's stock market price relative to the performance of the general market, which we proxy using the performance.

Therefore, this study evaluated the performance of the acquisition of ABSA Barclays through an accounting based measure.

\section{The research methodology}

To evaluate the performance of this acquisition, time series analysis or trend analysis were used (Sekaran and Bougie, 2016). The profitability ratios were used as an accounting based measure to evaluate perfor- 
mance (Wanke et al., 2016). Mayo (2016) indicated that the analysis of financial statements through ratios could be a very good tool to ascertain how the firm is performing over time and relative to its competition. The ratios indicates trends, such as a deterioration in the firm's profitability and time series analysis of financial statements may indicate future difficulties, while there is still time to take remedial action. These banks were chosen based on data publicly available for rational analysis and decision-making. Different financial ratios such as profitability ratios, Return on Assets, Return on Investment, Return on Equity and Debt Equity Ratio have been chosen to make analysis of these banks profitability. Financial ratios play an important role in analyzing business performance by measuring their improvement in the direction of their goals.

Further, this preferred methodology took a discursive approach review, because it evolved on analyzing already available data, in this case, the financial statements of ABSA before, during and after the acquisition (Creswell, 2013). This article adopted a discursive design. This is when the research approach is based on existing literature, rather than new experimental data. This approach is discursive, because it is based on information that is already available. The financial statements analyzed are already available to the public at the organization's website or previous publications such as newspapers. Further, this approach is a very purposive approach, because it looks at only 2004-2015 financial years of ABSA in order to evaluate the set hypothesis. In this article, different kinds of relevant formulae were used to analyze the information from ABSA financial statements. The information in the financial statements was considered as raw data for this article, hence, the need to use formulae to breakdown the data into information was used to aid the purposes of this study.

\section{Data collection and analysis}

There are several techniques being used to analyze a company's financial performance. An important one in analyzing the figures taken from a company's financial statement is the use of ratio analysis (Minnis and Sutherland, 2016). Indeed, financial statement analysis is vital, since past performance is usually a good indicator of future performance, and the current position is the platform upon which future performance will be built (Tayeh et al., 2015). Therefore, in this article, the researcher preferred to use the financial ratio analysis. Financial ratio analysis is the process of calculating financial ratios, which are mathematical indicators calculated by comparing key financial information appearing in financial statements of a business, and analyzing the financial statements to establish the rationale behind the business's current financial position and financial performance, and further projects its future outlook (Tayeh et al., 2015). Since, the study sought to evaluate the performance of ABSA Barclays Bank through an accounting based measure. The analysis focused on profitability ratios, such as Return on Assets (RoA), Return on Equity (RoE), Return on Investment (RoI), consisting of an advantage ratio Debt to Equity Ratio (DER). The data used in this study were gathered from the audited consolidated financial statements of ABSA Barclays South Africa for the period 2004-2015. The data are currently published and are available for public consumption in annual reports and audited financial statements of ABSA Barclays Africa. The sources provided a higher quality data, given that it was a permanent source of information, which enabled this article to relatively cross check the data easily, hence, taken to be reliable. Thus, the assessment of the financial performance of the company through the financial ratio analysis assessed what has been achieved in the pre- and post-acquisition of ABSA by Barclays Plc. Thus, to measure the company's financial performance, earnings growth were used, because profit was a fundamental tool to measure the performance of the acquired financial institution. According to the financial statements of $\mathrm{AB}$ SA/Barclays bank 2003-2015, the profit after tax for ABSA before the acquisition, in the year of the acquisition and the year after the acquisition was as presented in Table 1.

Table 1. Summary of financial results for ABSA/Barclays Plc

\begin{tabular}{|l|c|c|c|c|c|c|c|c|c|c|c|c|}
\hline & 2004 & 2005 & 2006 & 2007 & 2008 & 2009 & 2010 & 2011 & 2012 & 2013 & 2014 & 2015 \\
\hline Profit for the year (million) & 3282 & 4844 & 8266 & 10025 & 11317 & 7502 & 8589 & 10184 & 10746 & 12874 & 14144 & 15404 \\
\hline \multicolumn{10}{|c|}{ Basic earnings } \\
\hline Basic earnings per share (cents) & & & 1216 & 1428 & 1578 & 986 & 1133.3 & 1349 & 1180 & 1414 & 1560 & 1692 \\
\hline Diluted earnings per share & & & 1154 & 1348 & 1519 & 962 & 1126 & 1343 & 1178 & 1412 & 1559 & 1691 \\
\hline
\end{tabular}

Source: audited consolidated and separate financial statements of ABSA/Barclays South Africa. www.barclaysafrica.com.

These data were carefully analyzed and the limitations of these data were taken into consideration. Especially, the basic earnings and diluted earnings per share of 2004 and 2005 fi- nancial periods were not available from the audited financial statements. The following financial performance of the acquired bank was analyzed. 


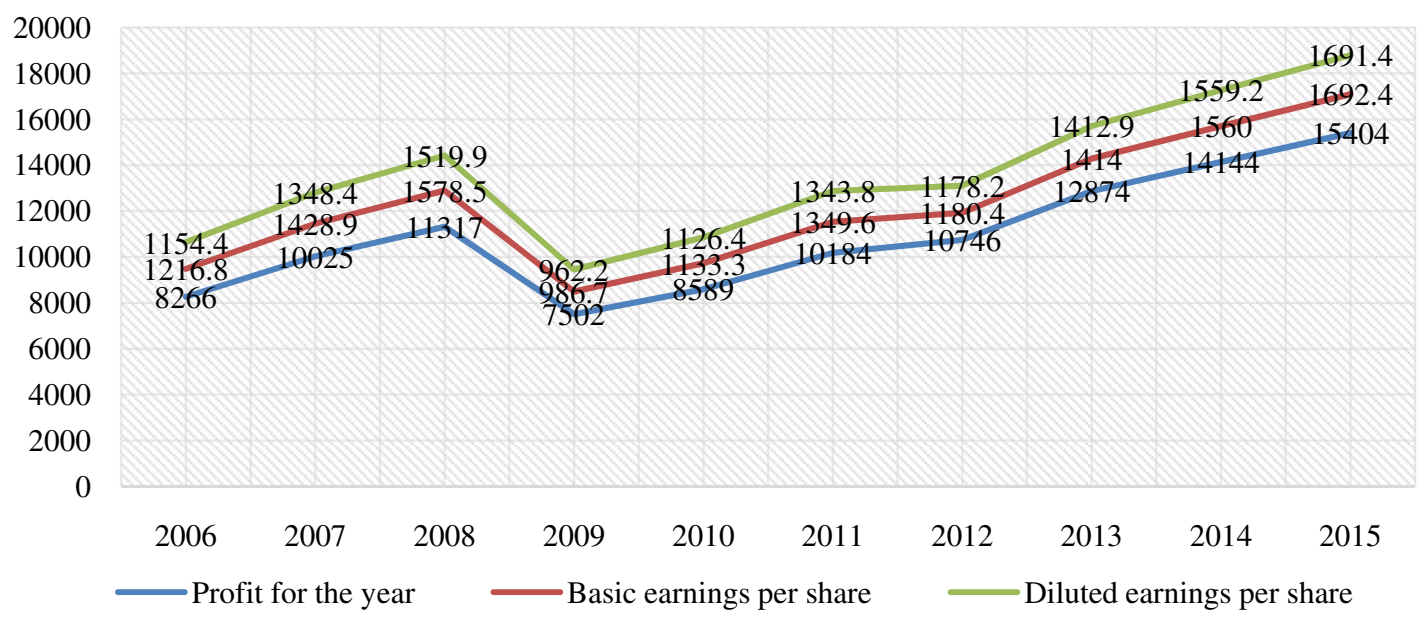

Fig. 1. The financial performance of the acquired Amalgamated Bank of South Africa for the period 2006-2015

Source: audited consolidated and separate financial statements of ABSA/Barclays South Africa. www.barclaysafrica.com.

The audited financial statements of ABSA (2005), the figures for the year 2005 are for a period of nine months ended on 31 December 2005. According to the profit realized for 2005 proportionally, for the twelve months' period, it might approximately be: $\frac{12 \text { months }}{29 \text { months }}$ x R 8266 million = R 11021 million.

The above assumption was based on the hypothesis that ABSA makes the same revenues every month to contribute to the profits equally at the year-end. The increase in profit by ABSA is an evidence so far that the acquisition is benefitting the South African economy. To evaluate the performance of this acquired bank, the following accounting measures were used.

3.1. The Return on Assets (RoA). Return on assets is the ratio of net income to total assets. Growth in earnings yield suggests that net income is increasing at a higher rate than the stock price, or due to factors that are not driven by market variables (Abraham, Harris \& Auerbach, 2017). Such factors may be intrinsic measures of operational efficiency represented by the ability to generate income from the firm's investment in assets. One of the measures of such operational efficiency is return on assets (Abraham et al., 2017). Correira, Flynn, Uliana, and Wormald (2014) confirmed that the return on assets is when a company can grow at the return on its assets if it does not pay any dividends and is not financed from outside sources, that is, if it is entirely financed by shareholders' funds. An asset is something valuable belonging to the organization that can be used for the payment of debts. Return on assets measures the rate at which the profit before tax can be able to cover the assets of the organization. The return on assets on this acquisition from 2004 to 2006 was found to be $1.53 \%$, $1.74 \%$ and $2.31 \%$, respectively.

3.2. Return on Equity (RoE). Ross, Westerfield, Jordan, and Firer (2012) define the return on equity as a measure of how the shareholders fared during the year. In other words, return on equity is to determine the rate at which the profits are being made by ABSA after tax can be able to cover the ordinary shareholder's equity (Ross et al., 2012). The Return on Equity (RoE) of this acquisition is another measurement of management performance. It tells how well a bank has used the capital from its shareholders to generate profits, taking into account the net income after taxes. It has indicated that the best rates were attained, i.e., $19.92 \%$ in $2004,18.63 \%$ in 2005 and $23.67 \%$ in 2006 .

3.3. Return on Investment (RoI). The money that was invested in this amalgamation can be recovered at this rate of the return on investment. In this case, the investments are the assets of ABSA. To calculate the return on investment, the net profit after tax was divided by the total assets of ABSA.

3.4. The Return on Equity (RoE). The results indicated an increase in the return on equity from 2004 to 2005 from $1.15 \%$ to $1.2 \%$. This is a small increase, as compared to the increase from $1.2 \%$ in 2005 to $1.67 \%$ in 2006 . With this, it is safe to assume that the acquisition benefitted ABSA as an organization, because analyzing the return on equity is one of the ways in looking at the impact of the acquisition on the organization itself.

3.5. The Debt to Equity Ratio (DER). The debt to equity ratio provides an indication of a company's or a bank capital structure and whether it is more reliant on depositors and shareholders' capital (equity) to fund its activities. Although a higher ratio indicates more risk, banks' higher ratio points to positive and negative indications; a positive indication for more clients' deposits, and a negative for other banks' deposits, loans, and allowances. DE ratio will be more meaningful when compared over a period of time, and between banks. The DER showed that before the acquisition, ABSA had a high DER meaning that to finance its business acti- 
vities, it used other people's money. As soon as the acquisition took place in 2005, the ABSA DER decreased significantly from $41.88 \%$ in 2004 to $24.93 \%$ in 2005 , as well as, after a year into the acquisition, the use of debt by ABSA decreased from $24.93 \%$ in 2005 to $24.11 \%$ in 2006 .

\section{Findings and conclusion}

The findings indicate an increase in profits from year to year for 2006-2008 and 2010-2015 periods, as reflected on the line chart in Figure 1. Therefore, it can be concluded that the acquisition of ABSA by Barclays Plc had a positive contribution to the South African national output. The Return on Assets (RoA) results shows that there is an effective management of company assets. The Return on Equity (RoE), as one of the accounting measures, reflected that ABSA has a favorable rate of profits after tax to cover the ordinary shareholders' equity. The Return on Investment (RoI) results are favorable. This could affirm that all the resources invested by Barclays in the acquisition of ABSA can be recovered in a long run. The debt to equity ratio (DER) of this acquisition revealed that before the merger, ABSA had a high DER to finance its business activities. However, after post-acquisition, the debt to equity ratio improved. This is confirmed by the findings that the ABSA DER decreased significant- ly from $41.88 \%$ in 2004 to $24.93 \%$ in 2005 . Further, within a year after the acquisition, the use of debt by ABSA decreased from $24.93 \%$ in 2005 to $24.11 \%$ in 2006.

The completion of a merger does not ensure the success of the resulting organization, because many mergers in some industries result in an overall loss of value due to unforeseen problems. Correcting problems caused by incompatibility, whether of technology, equipment, or corporate culture, diverts resources away from new potential investments, and this may be an immediate problem of most mergers, though nothing of this nature has been reported on ABSA Barclays merger. However, in mergers and acquisitions, there may be problems, which may be intensified by inadequate research or by concealment of losses or liabilities by one of the partners in the merger. Therefore, for the merger or acquisition not to be considered a failure, it must increase shareholder value more than if the companies were separate, or prevent the deterioration of shareholder value more than if the companies were separate. ABSA Barclays merger has, therefore, managed to contain these problems, as the merged organization has managed to increase share price value and thereby making the shareholders believe that the merger was profitable.

\section{References}

1. ABSA Annual Report. (2015). Annual Consolidated and Separated Financial Statements. Barclays Africa Group Limited. www.barclaysafrica.com (Accessed 07 December 2016).

2. Abraham, R., Harris, J., \& Auerbach, J. (2017). Earnings Yield as a Predictor of Return on Assets, Return on Equity, Economic Value Added and the Equity Multiplier. Modern Economy, 8, 10.

3. Ahmed, A., \& Nadeem, M. (2015). Mergers \& Acquisitions and Banks Performance in Pakistan.

4. Akhtar, S., \& Iqbal, J. (2014). An Empirical Analysis of Pre and Post Merger or Acquisition Impact on Financial Performance: A Case Study of Pakistan Telecommunication Limited. European Journal of Accounting Audting and Finance Research, 3, 69-80.

5. Alexandridis, G., Petmezas, D., \& Travlos, N. G. (2010). Gains from Mergers and Acquisitions Around the World: New Evidence. Financial Management, 39, 1671-1695.

6. Arvanitis, S., \& Stucki, T. (2015). Do Mergers and Acquisitions among Small and Medium-Sized Enterprises Affect The Performance of Acquiring Firms? International Small Business Journal, 33, 752-773.

7. Chen, C.-W., Collins, D. W., Kravet, T. D., \& Mergenthaler, R. (2016). Financial Statement Comparability and the Efficiency of Acquisition Decisions.

8. Claessens, S., \& Horen, N. (2014). Foreign Banks: Trends and Impact. Journal Of Money, Credit And Banking, 46, 295-326.

9. Collett, N. (2015). Mergers and Acquisitions. Wiley Online Library.

10. Creswell, J. W. (2013). Research Design: Qualitative, Quantitative, and Mixed Methods Approaches. Sage Publications.

11. Hitt, M. A., King, D., Krishnan, H., Makri, M., Schiiven, M., Shimizu, K., \& Zhu, H. (2012). Creating Value through Mergers and Acquisitions. The Handbook of Mergers and Acquisitions, 71.

12. Irfan Shakoor, M., Nawaz, M., Zulqarnain Asab, M., \& Khan, W. A. (2014). Do Mergers and Acquisitions Vacillate the Banks Performance? (Evidence from Pakistan Banking Sector). Research Journal of Finance And Accounting, 5, 123-137.

13. Lin, D., Barth, J., Jahera, J., \& Yost, K. (2013). Cross-Border Bank Mergers and Acquisitions: What Factors Pull and Push Banks Together? Review of Pacific Basin Financial Markets and Policies, 16, 1350022.

14. Linde, S., \& Siebert, R. (2016). Do Mergers among Multimarket Firms Create Value?

15. Mayo, H. (2016). Basic Finance: An Introduction to Financial Institutions, Investments and Management. Nelson Education.

16. Minnis, M., \& Sutherland, A. (2016). Financial Statements as Monitoring Mechanisms: Evidence from Small Commercial Loans. Journal of Accounting Research. 
17. Pahuja, A., \& Aggarwal, S. (2016). Impact of Mergers and Acquisitions On Financial Performance: Evidence From Indian Banking Industry.

18. Pilloff, S. J. (1996). Performance Changes and Shareholder Wealth Creation Associated with Mergers of Publicly Traded Banking Institutions. Journal of Money, Credit and Banking, 28, 294-310.

19. Roberts, A., Wallace, W., \& Moles, P. (2010). Mergers and Acquisitions. Pearson Education.

20. Ross, S., Westerfield, R., Jordan, B., \& Firer, C. (2012). Fundamentals of Corporate Finance, First South African Edition. London: Irwin.

21. Sabri, M. F. M., Ezman, S. M., \& Zainal, H. (2015). The Impact of Banks'merger and Acquisition Towards Stock Performance of the Rival Banks In Thailand.

22. Sekaran, U., \& Bougie, R. J. (2016). Research Methods for Business: A Skill Building Approach. John Wiley \& Sons.

23. Tayeh, M., Al-Jarrah, I. M., \& Tarhini, A. (2015). Accounting Vs. Market-Based Measures of Firm Performance Related to Information Technology Investments.

24. Uhlenbruck, K., Hughes-Morgan, M., Hitt, M. A., Ferrier, W. J., \& Brymer, R. (2016). Rivals' Reactions to Mergers and Acquisitions. Strategic Organization, 1476127016630526.

25. Uremadu, S., Nwokocha, E., \& Onyike, S. (2016). Effects of Mergers And Acquisitions On Commercial Bank Credit to Small Businesses In Nigeria.

26. Wanke, P., Maredza, A., \& Gupta, R. (2016). Merger and Acquisitions in South African Banking: a Network Dea Model.

27. Weinberg, M. (2007). The Price Effects of Horizontal Mergers. Journal of Competition Law and Economics, 4, 433-447.

28. Yadav, S. (2016). Performance Evaluation of Banking Sector in India. Sumedha Journal of Management, 5, 67. 